\title{
THE ROLE OF PRE-MARKET \\ FACTORS IN BLACK-WHITE \\ WAGE DIFFERENCES
}

\author{
Derek A. Neal \\ William R. Johnson
}

Working Paper No. 5124

\section{NATIONAL BUREAU OF ECONOMIC RESEARCH 1050 Massachusetts Avenue \\ Cambridge, MA 02138 May 1995}

We appreciate helpful discussions with Bo Honore and the assistance of Dr. Jane Arabian of the Department of Defense. We also acknowledge very useful comments by Joe Altonji, Rebecca Blank, Francine Blau, Steve Cameron, James Heckman, Joe Hotz, Larry Kahn, Alan Krueger, Bruce Meyer, Ed Olsen, Randy Olsen, Sherwin Rosen, Jon Skinner, James Smith, Steve Stern, Robert Topel, Finis Welch and workshop participants at McMaster, NBER, Northwestern, and the Universities of Chicago, Illinois, Toronto and Virginia and anonymous referees. Neal gratefully acknowledges support by the John M. Olin Foundation from its grant to the Center for the Economy and the State. A substantial portion of this research was completed while Johnson was visiting the Department of Economics at the University of Chicago. Opinions and remaining errors are ours alone. This paper is part of NBER's research program in Labor Studies. Any opinions expressed are those of the authors and not those of the National Bureau of Economic Research.

(c) 1995 by Derek A. Neal and William R. Johnson. All rights reserved. Short sections of text, not to exceed two paragraphs, may be quoted without explicit permission provided that full credit, including $(\mathcal{O}$ notice, is given to the source. 


\title{
THE ROLE OF PRE-MARKET \\ FACTORS IN BLACK-WHITE \\ WAGE DIFFERENCES
}

\begin{abstract}
Many attempts to measure the wage effects of current labor market discrimination against minorities include controls for worker productivity that (1) could themselves be affected by market discrimination and (2) are very imprecise measures of worker skill. The resulting estimates of residual wage gaps may be biased. Our approach is a parsimoniously specified wage equation which controls for skill with the score of a test administered as teenagers prepared to leave high school and embark on work careers or post-secondary education. Independent evidence shows that this test score is a racially unbiased measure of the skills and abilities these teenagers were about to bring to the labor market.

We find that this one test score explains all of the black-white wage gap for young women and much of the gap for young men. For today's young adults, the black-white wage gap primarily reflects a skill gap, which in turn can be traced, at least in part, to observable differences in the family backgrounds and school environments of black and white children.

While our results do provide some evidence of current labor market discrimination, skill gaps play such a large role that we believe future research should focus on the obstacles black children face in acquiring productive skills.
\end{abstract}

Derek A. Neal

Department of Economics

University of Chicago

Chicago, IL 60637

and NBER
William R. Johnson

Department of Economics

University of Virginia

Charlottesville, VA 22901 
The analysis of the black-white wage gap typically assigns some responsibility to the observable productive characteristics each group of workers brings to the labor market and treats the remaining residual of unexplained wage differences as a measure of current labor market discrimination. Most studies conclude that although differences in worker characteristics are important sources of black-white wage differentials, current labor market discrimination accounts for at least $1 / 3$ to $1 / 2$ of the overall gap.

In this paper, we attempt to address two well-known problems that have plagued numerous previous empirical studies of blackwhite wage gaps. ${ }^{1}$ First, some do not account for the fact that many productive characteristics are endogenous and can be affected by labor market discrimination. ${ }^{2}$ In empirical studies of blackwhite wage differences, researchers have included controls for characteristics such as occupation, post-secondary schooling, parttime work, marital status, geographical location, and actual labor market experience. ${ }^{3}$ Since all of these variables are subject to worker choice and could be contaminated by current labor market discrimination, controlling for them in wage regressions may misstate the wage effects of current discrimination.

${ }^{1}$ See cain (1986) for an analysis and survey of the literature on estimating the wage effects of discrimination.

${ }^{2} \mathrm{Blinder}$ (1973) was the first to distinguish between and to estimate structural and reduced form wage equations in the context of discrimination. Cain (1986) also discusses this issue.

${ }^{3}$ See the studies by Corcoran and Duncan (1979), Reimers (1982), Smith and Welch (1986), O'Neill (1990), Blau and Beller (1992) and Oaxaca and Ransom (1994). 
At the same time, most studies do not adequately address the fact that, on average, blacks and whites enter the labor market with different levels of skill. Although years of school is typically used as a measure of worker skill, this variable is less than satisfactory. To begin, years of schooling is an inherently noisy measure of worker skill because it measures an input, not an outcome. $^{4}$ Moreover, years of school may systematically overstate the relative skill of blacks. Evidence from standardized tests indicates that black children exhibit lower levels of achievement than white children in the same grade. ${ }^{5}$ As a consequence, analyses that rely on schooling as a measure of skill will likely overstate the effect of current labor market discrimination on wages and confuse the barriers that black children face in acquiring human capital with the obstacles that black adults face when they enter the labor market.

We use the National Longitudinal Survey of Youth to examine the black-white wage gap among workers in their late twenties. In our regressions, we control for a single measure of skill, the Armed Forces Qualification Test (AFQT). We argue that our approach improves upon previous work in this area because the test is taken by our sample before market entry and is therefore less likely to be contaminated by worker choices or labor market discrimination.

\footnotetext{
${ }^{4}$ Because blacks receive less formal schooling than whites, it is straightforward to show that this source of measurement error creates a bias toward overstating the magnitude of the black-white wage gap.
}

${ }^{5}$ See the High School and Beyond Survey of 1980. 
Further, as we show later on, independent studies verify that the AFQT is a racially unbiased measure of basic skills that helps predict actual job performance.

our results can be interpreted as estimates of the portion of the overall racial wage gap attributable to human capital formation before the age of 16 to 18 . Even though we do not observe every aspect of skill, our estimates will not overstate this portion unless blacks surpass whites in unobserved productive characteristics.

The first half of the paper presents the basic wage regressions and shows their robustness to alternative specifications or interpretations of the data. The second half of the paper explores some of the reasons black youth acquire less skill than whites. Family background variables that affect the cost or difficulty parents face in investing in their children's skill explain roughly one third of the racial test score differential. Measures of school environment account for part of the remaining gap in test scores.

While we find some evidence of labor market discrimination, we conclude that the disadvantages young black workers now face in the labor market arise mostly from the obstacles they faced as children in acquiring productive human capital. Our analysis suggests that public policy focus on the plight of black children in acquiring skills valued by the labor market. 
I. The Basic Result

The model underlying our empirical results views the amount of human capital youths have attained by their late teens as a predetermined initial condition that constrains the future path of human capital, and hence future wages. After the late teens, further investments in human capital, work experience, and occupation are endogenous choices that affect wages but are constrained by the initial level of human capital. Therefore, using post-secondary education, experience, and occupation as regressors in a wage equation would bias our estimate of the effect of race on wages if discrimination against blacks causes them to choose different jobs and training opportunities than whites. Instead, we look at reduced form wage equations that include only variables that are exogenous or determined before labor market entry: ethnicity, gender, age and test score. ${ }^{6}$ These reduced form wage equations are appropriate because we are primarily interested in the total effect of race on wages after age eighteen, not the partial effect conditioning on endogenous covariates. We can then estimate the share of the total racial wage gap determined by the time a young person is in his or her late teens.

${ }^{6}$ One might also view location at labor market entry as truly exogenous to labor market discrimination. We conducted similar analyses with controls for region of residence and found that the controls have little effect on our results. 
Ideal data for estimating the effect of labor market discrimination on black-white wage gaps could be generated by a social experiment which observes a group of identically skilled teenagers both toward the end of secondary school and later during their labor market careers. Everything relevant for wages that happens to them after secondary school could be affected by discrimination -- post-secondary schooling, marriage, occupation, on the job learning, and so on. The wage gaps observed during their careers would then represent the cumulative effects of labor market discrimination. ${ }^{7}$

Instead of ideal experimental data, we use a sample of individuals for whom we have a good measure of skill that is not directly affected by career choices or labor market discrimination because the measurement is taken just before these workers enter the labor market or make important choices about schooling. Such a sample can be found in the National Longitudinal Surveys of Youth (NLSY), a panel data set of 12,686 young people born between 1957 and $1964 .^{8}$ The NLSY consists of both a nationally representative cross-section sample and a supplemental sample designed to oversample blacks, hispanics and low income whites. The oversamples of blacks and hispanics represent random samples for the black and

\footnotetext{
${ }^{7}$ Here, we are assuming that there are no racial differences in discount rates or the willingness to supply labor. Therefore, among individuals who begin their careers with equal levels of skill, wage differences reflect either differences in pay holding current skill constant or differences in human capital investment opportunities.

${ }^{8}$ The data are described in more detail in Appendix Table I. A data file is available from the authors upon request.
} 
hispanic populations. Our analysis combines the cross-section sample and the supplemental samples of blacks and hispanics. The resulting sample contains random samples within racial or ethnic groups, although as groups blacks and hispanics are overrepresented. 9

In 1980, the Armed Services Vocational Aptitude Battery (ASVAB) was administered to over $90 \%$ of the members of the NLSY panel. ASVAB is a set of 10 tests, of which a subset of four comprises the Armed Forces Qualification Test. ${ }^{10}$ The military services use the AFQT for enlistment screening and scores on various parts of the entire ASVAB for job assignment within the military. When the AFQT was administered in 1980 , the NLSY panel, born between 1957 and 1964, ranged from 15 to 23 years old. The older youth in this group had already entered the labor force as full-time workers and/or proceeded to post-secondary education. Job experience and post-secondary education surely enhance human

${ }^{9}$ This is perfectly appropriate as we are interested in comparisons of groups.

${ }^{10}$ There are two different scoring systems for the AFQT. The 1980 version employs ASVAB scores from the paragraph comprehension, arithmetic reasoning, word knowledge, and numerical operations tests. The 1989 version employs the mathematics knowledge score instead of the numerical operations score. Here, we use the 1989 scoring system.

In an earlier version of this paper, we reported results based on the 1980 version. In almost every specification, black-white wage gaps are slightly smaller using the 1980 version as a control for pre-market skill. Further, the correlations between wages and the 1980 version are a little stronger for all racial groups. Nonetheless, we employ the 1989 version because the military validation studies relating to racial fairness are more exhaustive for this later version. 
capital and will therefore increase test scores. If discrimination limits access to these human capital investments, then post-entry discrimination contaminates the test scores. To reduce this possibility, we restrict the sample to those younger members whose schooling choices would by and large be constrained by compulsory schooling laws and who would not have entered the labor market full time by 1980 . We analyze respondents born after 1961 who would have been eighteen or younger when they took the AFQT. Most of this group had neither entered the labor market full time nor started post-secondary schooling when they were tested." As a consequence, neither discrimination in the labor market nor in post-secondary education could directly affect the test performance of blacks in this young cohort.

The results presented in the paper are for this younger subset of the NLSY panel which we feel provides the cleanest estimates of residual wage gaps. However, we have estimated every specification using the full sample and find that the implied black-white differences in the means of the wage offer distributions are slightly smaller. To the extent that blacks enjoy less access to learning opportunities in the labor market and post-secondary education, this pattern is to be expected. ${ }^{12}$

"No respondent in this sample had completed a year of schooling beyond high school by May 1980 and less than one percent had even enrolled in college by this date. The AFQT was administered in the summer of 1980 .

${ }^{12}$ Since, for older workers, the skills measured by AFQT partly reflect post-secondary learning through formal schooling or job experience, controlling for AFQT in a wage equation on older cohorts creates the same bias induced by controls for occupation 
Columns (1) and (4) of Table I show simple regressions of log wage rates in 1990 and 1991 (when this sample was age 26 - 29) on age and ethnic or racial group dummies for men and women, respectively. ${ }^{13}$ The coefficients on black, -.244 and -.185 , are measures of the unadjusted log wage gaps between blacks and whites. We seek to explain these gaps.

The usual approach is to control for skill with a schooling variable. When years of schooling (in 1991 when wages are observed) is used as the measure of skill (as shown in columns (2) and (5) of Table I), it reduces the unadjusted wage gap by only $1 / 5$ for men and only $1 / 6$ for women.

Using the AFQT score as the measure of skill in the log wage regressions produces our central results, shown in columns (3) and (6) of Table I. ${ }^{14}$ since panel members took the AFQT at different ages and scores clearly rise with age, we adjusted the raw AFQT score for age at the test date and also normalized the score so that the sample mean is zero and the standard deviation is one. our normalized AFQT variable is highly significant in the wage regression and reduces the magnitude of the coefficient on black to

and work experience.

${ }^{13}$ The wage variable is the log of the mean of real wages in 1990 and 1991 for workers who worked in both years, and the log of the real wage in the year of employment for workers who worked in only one year. Those who worked in neither year have no wage data and are excluded from these regressions.

${ }^{14}$ The square of $\mathrm{AFQT}$, intended to capture deviations from loglinearity, is not significant here but is included to preserve comparability with later specifications. In a few instances, the deviation from linearity is significant. 
-.072 for men and +.035 for women. ${ }^{15}$ This test score explains nearly three quarters of the racial wage gap for young men and all of the gap for young women. Moreover, unreported results, using wage rather than $\log$ (wage) as the dependent variable, show small statistically insignificant race differences in wages for either sex when AFQT is included. ${ }^{16}$

The wage regressions in columns (3) and (6) show that the average marginal effect of a standard deviation of test score on log wages is roughly .2 for both men and women. Since the black mean test score for each sex is about a standard deviation lower than the corresponding white mean, the test score gaps account for large portions of the black-white log wage gaps of -.18 and -.24 found for women and men, respectively.

Some have argued that our specification should include controls for both AFQT and either years of total schooling or years

${ }^{15}$ Holding AFQT constant, black and Hispanic women earn more than white women. For Hispanic women the effect is large and statistically significant. Murnane, Levy, and willett (1994) report similar skill adjusted gaps using data on twenty four year old women. Their approach differs because they employ controls for not only worker skill but also work history and family background.

Selection effects may contaminate estimates of racial wage gaps for women. Among black, hispanic, and white women, the mean of observed wages will likely overstate the mean of the wage offer distribution. If this selection effect is more pronounced in the minority samples, ols regressions involving the wages of participants will understate the wage costs of racial discrimination suffered by women. Further, if we are willing to assume that highly skilled minority women have less non-earned income than their white counterparts, we might expect greater selection in the minority samples.

${ }^{16}$ In these regressions, similar to those in Table $I$, black men earn \$.27 per hour less than white men and black women earn $\$ .03$ per hour more than white women, but neither difference is statistically significant. 
of schooling following the AFQT. We prefer the AFQT only specification for several reasons. Given AFQT, schooling measures serve as proxies for skills that are either not captured by AFQT or are acquired after the test date. In either case, schooling is an indirect measure of these skills and it is straightforward to show that given the other controls in our specification, this source of measurement error introduces a bias toward overstating the blackwhite wage gap. ${ }^{17}$ Further, as we noted previously, this bias will be magnified if years of schooling is not only a noisy measure but also one that systematically overstates the relative skill of blacks. ${ }^{18}$ Finally, in our sample, schooling completed after the AFQT is primarily schooling completed beyond the age of compulsory attendance and is therefore endogenous. Post-secondary schooling decisions are based in part on expected pecuniary returns from further educational investments, which will, in turn, be affected by patterns of discrimination in the labor market. Our goal here is not to document all the ways that discrimination might affect career paths, but instead to provide a summary measure of the

\footnotetext{
${ }^{17}$ Using residuals from two auxiliary regressions one can show that the measurement error in the schooling variables biases the estimated coefficient on black downward.

${ }^{18}$ The AFQT is a test of verbal and math skills only. Data from the High School and Beyond Survey of 1980 show that among high school students in the same grade, means scores for black children fall well below the means for whites on not only tests of math and verbal achievement but also tests of writing, science, and civics achievement.
} 
effect of current labor market discrimination on wages. ${ }^{19}$

Nonetheless, for completeness, we provide an appendix table with results from three different specifications that include controls for both AFQT and measures of either total schooling or schooling completed after the AFQT. ${ }^{20}$ Because the estimated returns to schooling conditional on AFQT are significantly greater for blacks than whites, we estimated each of the specifications separately for blacks and whites. Then, for each specification, we formed two estimates of the black-white wage gap, one based on the samples means of observed characteristics in each sample. Our six estimates of the conditional log wage gap range from -.054 to .093. The median of these six estimates is -.075 . So, while we prefer the specification without any schooling variables, results from the specifications which include them support our main conclusions. ${ }^{21}$

It is useful to compare these results with other studies, many of which use different data sets and a wider range of ages than we do. O'Neill's 1990 study employs the 1980 version of the AFQT as a measure of skill in wage equations on NLSY data. O'Neill derives

${ }^{19}$ Separate analyses of the black and white samples show that among students with identical age-adjusted AFQT scores, blacks earn higher returns to additional schooling, and, in fact, complete about two quarters more of additional post-AFQT schooling.

${ }^{20}$ In Appendix Table II, we employ (i) total grades completed by 1991, (ii) grades completed after taking the AFQT, and (iii) dummies for high school and college graduation.

${ }^{21}$ Among women, the estimated black-white wage gaps are small conditional on these measures of education. Further, in five of six cases they are statistically insignificant. 
black-white wage gaps for men between 22 and 29 years of age. Her regressions of $\log$ wages on total years of schooling, potential experience, region and AFQT imply estimates of the residual blackwhite gap that range from -.046 to -.101 . When she includes additional controls for industry, occupation and actual work experience in her regressions, the black-white wage gap disappears.

All of O'Neill's specifications include controls that may be affected by current labor market discrimination. ${ }^{22}$ In addition, it appears that O'Neill's analysis included the NLSY supplementary sample of economically disadvantaged whites. For these reasons, o'Neill's results may understate the effects of current labor market discrimination. ${ }^{23}$

Oaxaca and Ransom (1994) used CPS data on men over 25 and found a log wage gap between blacks and whites of -.221 , which fell to -.125 with controls for observable characteristics. Reimers (1982) found an unadjusted log wage difference of -.233 in the Survey of Income and Education data on men of all ages, with an adjusted gap of .132. Corcoran and Duncan (1979) estimated the

${ }^{22}$ AFQT is endogenous in her sample because she includes people who were age 19 to 23 when they took the test and therefore may have started post secondary schooling or full-time work.

${ }^{23}$ Further, O'Neill includes workers who are 22 to 25 years of age in her wage regressions, ages at which wage differences are likely to understate lifetime differences in earning capacity. The hypothesis that o'Neill's results understate the black-white wage gap is supported by the fact that the unadjusted wage gap is smaller in her sample than in our study and others similar to it.

In related work on returns to educational quality, Maxwell (1994) also notes that, among men, controls for AFQT reduce blackwhite wage gaps substantially. 
residual black-white wage gap for men of all ages in 1975 using an extensive list of variables from the PSID, but could explain only 53\% of it. Even though all these studies use many independent variables as controls, we can account for a greater portion of the unadjusted wage gap with a single measure of skill.

Phillips Cutright's 1973 study relating AFQT's for Korean War draftees to their earnings in 1964 yields results roughly similar to ours for whites, but a much lower payoff to skill for blacks. As a result, he finds that AFQT explains only a quarter of the black-white wage gap, which is a much smaller fraction than our results in Table I suggest. The contrast between our results for 1990-1 wages and Cutright's results for 1964 is consistent with the well-documented advance in the relative wages of blacks that occurred after the civil rights legislation of the mid-1960's. ${ }^{24}$

We now discuss possible objections to our interpretation of the results in Table $I$.

\section{Is the AFOT racially biased?}

An obvious objection to our interpretation of Table $I$ is that the AFQT is a racially biased test in the sense that its scores underpredict productivity or job performance for blacks compared to whites. For many tests, it would be impossible to judge the validity of such an assertion because we typically have no way of directly measuring job performance and relating it to the test

${ }^{24}$ See Freeman (1981) and Donohue and Heckman (1991). 
scores received. ${ }^{25}$ However, in 1991 the National Academy of Sciences (NAS) completed an exhaustive study with the Department of Defense of the validity of the AFQT with special emphasis on the racial fairness of the test. The unique aspect of the NAs study is that job performance was measured without using either supervisor evaluations or written tests, two methods that could be seen as introducing racial bias. ${ }^{26}$ Instead, for several military occupational specialties direct measures of performance on the tasks comprising the job were undertaken. As an example, the job of infantry rifleman in the Marine Corps was broken into 15 tasks and each task further divided into subtasks. Subtasks were small enough that performance could be evaluated by $a(1,0)$ yes-no scoring system, which ensured a high degree of consistency across evaluators. Military job experts designed a weighting system that translates the subtask scores into a composite job performance measure. ${ }^{27}$ Then these "hands-on" measures of job performance were regressed on the AFQT score of the individual at the time he or she

${ }^{25}$ Obviously, the possibility of wage discrimination precludes using wage data to test the racial bias of the test.

${ }^{26}$ Discriminating supervisors could give blacks lower evaluations than whites conditional on actual performance. Moreover, if blacks do poorly on written tests compared to whites with the same actual knowledge or performance skill, then validating a written test's prediction with a performance measure based on a written test could falsely imply no racial bias.

${ }^{27}$ Examples of tasks tested are land navigation, squad automatic weapons, first aid, night vision device, rifle, live fire, etc. See Wigdor and Green (1991). 
enlisted in the military. ${ }^{28}$

How well does AFQT predict military job performance? For the 23 military occupations studied ${ }^{29}$, the correlations between AFQT scores and job performance ranged from .13 to .49 , with a median correlation of $.38 .{ }^{30}$ The more important question, however, concerns racial bias, a key issue for the NAS panel. They concluded that AFQT does not systematically underpredict black job performance relative to white performance: " . for practical purposes the same regression lines predicted performance about as well for both groups." 31 If anything, test scores slightly overpredict job performance by blacks. We view the NAS findings as strong independent verification that the AFQT can be considered a racially unbiased predictor of success in acquiring new skills in the military, and we have no reason to believe that the AFQT would be a racially biased predictor of success in acquiring civilian job

${ }^{28} \mathrm{~A}$ selection effect operates here because individuals with very low AFQT scores would not be allowed to enlist in the military. The observation that AFQT predicts job performance without racial bias applies, strictly speaking, only to the range of AFQT scores observed in the military.

${ }^{29}$ For a complete list of military occupational specialties studied, see wigdor and Green (1991, p 161).

${ }^{30}$ These correlations are likely to understate the correlation between AFQT and a general skill or capacity to learn a specific task because selection into military occupational specialties is accomplished in part with test scores. Hence the range of test scores for any particular job is truncated.

${ }^{31}$ Wigdor and Green (1991, p. 179). At the mean level of black test scores, the average overprediction of black performance, in standardized units, is .15 when the job includes at least 75 blacks tested. (Wigdor and Green (1991, p. 178). Overprediction also occurs on average for jobs with smaller samples of blacks. 
skils.

Do blacks underinvest in skill because the return is lower?

Models of discrimination developed by Arrow (1973) and Lundberg and startz (1983) yield discriminatory equilibria from black-white differences in the return to acquiring skill. In both models, blacks with more skill have more difficulty distinguishing themselves to employers than high-skill whites and therefore the payoff to acquiring skill is lower for blacks. Our results in Table I indicate that blacks and whites. earn different wages in large part because they typically begin their careers with different levels of human capital. These models of discrimination highlight the possibility that black youths enter the labor market with relatively few skills simply because they anticipate that the returns from acquiring skills will be low.

We investigate this possibility in Tables II and III. While we have no direct evidence about the expectations of these youth, we can look for differences between blacks, whites, and hispanics in the realized effects of AFQT scores on civilian wages. The regression equations reported in the first columns of both Table II and Table III include an interaction between black and AFQT. For men, there is some indication that black men fare relatively better at the high end of the AFQT distribution. For women, the opposite is true. However, for both sexes, the estimated coefficients on 
the interaction terms are jointly insignificant. ${ }^{32}$ The remaining results in Tables II and III show the marginal effect of AFQT on log wages for each racial group. There are small, statistically insignificant black-white differences for men in Table II, and columns (2) and (3) of Table III show that AFQT exerts an almost identical effect on the wages of black and white women. For both black and white men and women, the law of one price roughly holds for skill as measured by AFQT. ${ }^{33}$ Nonetheless, since the cutright (1973) study found that the return to skill investment was lower for blacks in 1964, we cannot rule out the possibility that the young black adults in the NLSY expected lower returns to skill when they chose levels of investment. Our data cannot address this issue.

What about the Labor Market Dropouts?

The work of Butler and Heckman (1977) and Brown (1984) has alerted labor economists to the importance of considering differences in labor force participation by race in estimating wage differences. Since we do not know market wages for non-

\footnotetext{
${ }^{32}$ Under the null that the coefficients on both interaction terms are zero, the F-statistics for the male and female regressions are 2.20 and 2.17 respectively.

${ }^{33}$ We are puzzled by the fact that hispanic men are the only group that earns considerably less per unit of test score. However, the inclusion of hispanics in our analysis does not greatly effect our results. Our estimate of the conditional blackwhite wage gap changes little when we drop hispanics from the sample.
} 
participants, they are typically dropped from standard wage equations (as they were from the regressions reported in Tables $I$, II and III). In the male sample, labor market dropouts are disproportionately black and are likely to have relatively low wage offers. Figure 1 shows that, at most levels of AFQT, labor force participation rates for black men are lower than the rates for white men. ${ }^{34}$ The exclusion of non-participants could understate the effect of race on the mean of the male wage offer distribution. One way to address the selection problem is to model the labor force participation decision explicitly and estimate a structural model of wage offers and participation. However, the difficulty of identifying such a model led us to consider other approaches. ${ }^{35}$

We cannot make inferences about the wage offer distribution without some assumption concerning the wage offers of nonparticipants. Suppose all non-participants have wage offers below the median offer made to workers with comparable skills. In this case, we can estimate medians of conditional log wage offer distributions by assigning non-participants an arbitrarily low

${ }^{34} \mathrm{~A}$ participant is defined as someone who worked at some time since the last NLSY interview. Interviews are about a year apart. This definition is not the same as the CPS definition which is whether one worked last week. Our measure will, of course, yield higher rates of participation.

${ }^{35}$ Identification is achieved in such models either with exclusion restrictions or assumptions about the functional form of the error term. Exclusion restrictions are problematic in the case of male workers because it is difficult to conceive of a variable which affects participation but does not affect the market wage. 
wage. ${ }^{36}$ Under the additional assumption that the means and medians of the conditional log wage offer distributions are equal, this approach yields a consistent estimate of the black-white gap in mean $\log$ wage offers.

To illustrate, suppose the best wage offer for worker i is a log-linear function of characteristics:

(1) In(wage offer $)=\beta_{\mathrm{w}}$ white $_{\mathrm{i}}+\beta_{\mathrm{b}}$ black $_{\mathrm{i}}+\beta_{\mathrm{h}}$ hispanic $_{\mathrm{i}}+$

$$
\alpha \mathrm{AFQT}_{\mathrm{i}}+\epsilon_{\mathrm{i}}
$$

where $\epsilon_{i}$ is an independent draw from a distribution $G\left(\epsilon_{i}\right)$, whose mean and median are both zero. The effect of race on the mean of the log wage offer distribution is the same as the effect of race on the median of the log wage offer distribution, namely $\beta_{b}-\beta_{w}$. Consider a group of individuals with identical characteristics. If all the non-participants in that group have wage offers less than the median wage offer for the group and if more than half participate, then the median of the log wage offer distribution is the same as the median of the distribution formed by adding the non-participants to the bottom of the observed market log wage

\footnotetext{
${ }^{36}$ We do not pursue a similar strategy with the female sample, in part, because this assumption seems implausible for women. The women in our sample are in their late twenties. For this group, child care demands may be an important factor in participation decisions. Therefore, the link between wage offers and participation may be weakened.
} 
distribution. ${ }^{37}$ In our data, hourly wages are measured in cents. Therefore, we construct our sample of $\mathrm{log}$ wage offers by assigning log wages of zero to all male non-participants. This strategy ensures that our imputed offers for non-participants always fall below the relevant conditional medians. Table IV presents median regression results based on this sample.

The racial wage gap at the median moves from -.352 to -.134 when AFQT is added to the regression. These median regressions, with and without conditioning on AFQT, show a larger negative effect of being black than did the regressions on participants in Table I, where the adjusted gap for men was -.072. The contrast between the results at the mean and at the median support the view that looking only at participants masks some discrimination. However, the fact remains that over $60 \%$ of the difference in medians is explained by our one measure of skill.

The above methodology is only one way of estimating the racial difference in the conditional means of the wage offer distributions. Smith and Welch (1986) use a different method. They start from the fact that the mean of the wage offer distribution, $E(w)$, is a weighted average of the mean wage offers for participants and non-participants,

$$
\begin{aligned}
E(w)= & \text { LFPR } E(w \mid \text { participate })+ \\
& (1-\text { LFPR }) E(w \mid \text { don't participate }) .
\end{aligned}
$$

\footnotetext{
${ }^{37}$ Even at very low AFQT scores, our data show participation rates of men well above $50 \%$.
} 
The ratio of the means of the wage offer distributions facing two groups, $i$ and $j$, can therefore be written as:

$$
E\left(w_{i}\right) / E\left(w_{j}\right)=\left\{E\left(w_{i} \mid \text { participate }\right) / E\left(w_{j} \mid \text { participate }\right)\right\} B,
$$

where $B$, the selection bias, is equal to

$$
\begin{aligned}
& B=\left[\left(1-k_{i}\right) L F P R_{i}+k_{i}\right] /\left[\left(1-k_{j}\right) L F P R_{j}+k_{j}\right], \\
& \text { and } k_{i}=E\left(w_{i} \mid \text { don't participate) } / E\left(w_{i} \mid\right. \text { participate). }\right.
\end{aligned}
$$

Conditional on the sample labor force participation rates of each group, we can derive $B$ for various values of $k$, the ratio of the means of non-participant wages to participant wages. ${ }^{38}$ If $k_{w}=$ $k_{b}$, then $k$ must be .1 or less in order to generate the selection bias implied by the difference between our mean and median regression results. To see this, note that the mean gap of -.072 $\log$ points implies a black/white wage ratio of .931, while the median gap of -.134 yields a selection corrected ratio of .875 . The ratio of these two is .94 . If we assume that $k_{b}=k_{w}=.1$ and use the sample labor force participation rates as proxies for the

${ }^{38}$ It is obviously difficult to measure this quantity directly. Smith and Welch compare the wages of individuals who participate intermittently with those who participate all the time, but that probably is an upwardly biased measure because those who do not participate at all, whose wages are never observed, likely have the lowest wage offers. Another approach is to make distributional assumptions about the wage offer distribution and then infer the unobserved lower tail from the observed accepted wages. 
true probabilities of participation, the Smith-Welch bias formula gives $\mathrm{B}=.94 . .^{39}$

The difference between the race effects in the mean and median regressions shows that selection bias may contaminate our oLs estimates of black-white wage gaps. However, using the Smith-Welch method, we cannot generate such a large correction for selection bias unless we are willing to assume that the mean wage offer of non-participants is one tenth of the mean offer among observationally similar participants. Since equation (4) follows directly from basic statements about conditional expectations, we feel comfortable viewing the -.134 gap as an upper bound on the absolute value of the black-white gap in mean wage offers. Further it is important to realize that our selection correction is driven by the relatively low participation rates among unskilled black men. The participation behavior of moderate to high ability black men resembles that of comparably skilled white men. ${ }^{40}$

\footnotetext{
${ }^{39}$ For $k^{\prime} s$ equal across the races, the bias is greatest when both are zero (see equation (4)). Then the correction factor $B$ is just the ratio of labor force participation rates, or $.86 / .924=$ .93 for the lowest ability group. The corrected wage ratio would be $(.93)(.942)=.877$. But this is just for the lowest ability group. The total correction factor would integrate over all ability levels and would be closer to one than .93 because the lowest ability group has the greatest racial difference in participation rates.

${ }^{40}$ Among workers in all but the lowest skill groups, black women participate more than comparable white women and do not suffer a wage disadvantage.
} 
Are blacks excluded from the best jobs?

The regression results presented so far have compared the means and medians of the conditional wage distributions for blacks and whites. Discrimination might compress the wage distribution for blacks, excluding them from jobs at the upper tail of the distribution, without exerting much effect at the mean. There are two distinct senses in which this could happen. First, highskilled blacks could face greater discrimination so that blackwhite differences would be greater at the upper end of the skill distribution. Second, blacks could be excluded from the best jobs open to workers with any particular level of skill. The first possibility is discounted by the results using the interaction of black and AFQT (shown in column (1) of Tables II and III) because if the black-white gap widened at high levels of skill the interaction between black and AFQT would be negative. Among women, the black-white gap does widen slightly at higher skill levels. However, the reverse is true among men. Further, the estimated interactions are statistically insignificant in both cases.

The second scenario, that of a greater gap at the upper tail of the conditional wage distribution can be tested by looking at quantile wage regressions which control for AFQT, reported in Tables V and VI. Among men the adjusted gap is still significantly negative at the 75th percentile, but the gaps get smaller as one moves to the upper tail of the conditional wage distribution. That 
is, the gap is smaller at the 90th percentile than at the 75 th, which in turn is smaller than the gap at the median. There is no evidence here of greater discrimination at the upper tail of the conditional wage distribution. Among women, there is a negative gap for black women at the goth percentile of the conditional distribution. However, this gap is not statistically significant.

How Well does the Wage Gap at Age 30 Represent the Lifetime Gap?

our data restrict us to looking at labor market outcomes for workers in a fairly narrow age range (age 26-29). One might object that evidence on wages of young adults cannot be used to make inferences about the wage gap for the rest of the life cycle. If the lifetime trajectories of $\log$ wages for whites and blacks were parallel, one could extrapolate the results here to say something about lifetime earnings. However, if discrimination in the labor market prevented blacks from investing heavily in on-thejob experience, then blacks would have flatter log wage trajectories and the wage gap would widen with age. Unfortunately, there is contradictory evidence about the blackwhite wage gap over the life cycle. Smith and Welch (1986) generally find narrowing of the unadjusted gap in decennial census data through 1980 as a cohort ages. However, Boozer, Krueger and walkon (1992, p. 317) include 1990 data and show that for older cohorts (born before 1940) the wage gap has narrowed over the life cycle, while for younger cohorts, the reverse is true. Whether 
the pattern of these younger cohorts will be maintained over time is an open question. Further, for a given cohort, trends in the overall black-white wage gap may be different than trends in the gap conditional on pre-market skill. ${ }^{41}$

II. The Determinants of AFQT scores

Having established the importance of the AFQT score as a measure of the skills young workers bring to the labor market and as an explanation for lower wage rates among blacks, the natural question is "Why do blacks score lower on this test?" Figures 2 and 3 show the sample distributions of test scores by race for men and women respectively. Over $35 \%$ of black men score below -1.0 while less than $10 \%$ of white men do. Again, we stress that we view the test as a test of achievement and learned skill not of innate ability, so we seek reasons that black youth have acquired less skill than white youth. Since the payoff to acquiring skill is roughly the same for black and white women and men, we conclude that the investment differential between the races is likely to be driven by differences in the costs of acquiring skill. Why do black youth (and their parents) find it more costly to invest in

${ }^{41}$ Since blacks receive .5 year more of schooling than whites, conditional on AFQT, black lifetime earnings will be slightly less than white lifetime earnings, conditional on AFQT, even if blacks and whites with the same AFQT scores earn the same wages throughout their working careers. However, on their own, the earnings foregone from that extra time spent in school are not large enough to preclude our use of current wage gaps as proxies for differences in lifetime earnings. 
skill than white youth? obviously, past and current discrimination against black families affects the constraints black parents face in investing in their children. For example, if education and high income make it easier to invest in children's human capital, then part of the racial difference in AFQT scores can be attributed to racial differences in parental education and income.

Table VII documents the extent to which observed aspects of family background account for the observed black-white gap in AFQT scores for men. Column (1) of Table VII sets the stage by estimating the unexplained score differences for men in the sample we have used for Tables I through VI, those born after 1961. As column (1) shows, the mean black score is one standard deviation below the mean white score, with Hispanics about .7 of a standard deviation below. The corresponding result for women, in Table VIII, shows only a slightly smaller black-white score differential.

The NLSY data include many variables describing the household in which the respondent was raised. In column (2), we present results from a specification that includes controls for the parents' capacity to provide human capital for their children. ${ }^{42}$ The results show that the achievement of children on the AFQT varies positively with the education and professional status of their parents. Further, given these controls, the black-white gap in scores falls to -.70 for men and -.72 for women.

\footnotetext{
${ }^{42}$ Since parents' characteristics are not known by youth who did not know their parents, we include indicator variables for knowledge of each parent in these regressions.
} 
These measures of family background serve only as rough measures of parental resources, and although it would be difficult to construct precise measures, we do know that parental resources affect optimal choices regarding the tradeoff between family size and child quality. Further, holding family size constant, we expect that, on average, investment in children will vary positively with parental resources. Therefore, column (3) introduces additional controls for family size and parental investment. Both number of siblings and our measures of family reading materials are strongly correlated with test scores. Further, the black-white gaps in scores fall to -.62 for women and -.57 for men when they are included.

Schools differ geographically in many observed dimensions, and residential segregation by race may also affect parents' capacity to invest in their children. Columns (4) in Table VII and in Table VIII report an AFQT regression with several school characteristics included: student-teacher ratio, disadvantaged student ratio, student dropout rate and teacher turnover rate. ${ }^{43}$ Each works in the expected direction, and together they further reduce the unexplained AFQT gap between blacks and whites. The residual gap

${ }^{43}$ The NLSY school survey obtained information directly from the high school the respondent last attended. Unfortunately, the sample sizes are smaller for this analysis because many schools did not respond. Only .45 of the black students have valid responses for the items used here. The corresponding figure for whites is .57 . 
falls to -.42 for men and -.58 for women. ${ }^{44}$

Even with our controls for both family and school environment, sizeable black-white gaps in AFQT remain. However, we account for a significant fraction of the overall gap using only a few measures of family background and secondary school environment. Elementary school environments may also be important, but we cannot investigate this hypothesis.

At this point, we want to restate our contention that the black-white gap in AFQT scores reflects differences in acquired skills. Recently, Herrnstein and Murray (1994) have generated significant controversy by using AFQT as a measure of inherent ability. Specifically, Herrnstein and Murray claim that AFQT is an approximately exogenous measure of cognitive ability that is not greatly affected by additional schooling or other human capital investments. However, we investigated this issue and reached a different conclusion. We discuss two sets of results that are inconsistent with the claims made by Herrnstein and Murray.

Appendix Table III presents four regressions of standard AFQT scores on dummies for race and year of birth. The regressions provide estimates of the black-white gaps in standard scores not only for the sample of respondents who took the test at age 18 or younger but also for those who were between 19 and 23 at the time

${ }^{44}$ Boozer, Krueger and Wolkon (1992) argue that black students suffer from racial isolation in school and less access to computers, both of which act to reduce their wages as adults. In contrast, Grogger(1993) finds little direct effect of school characteristics on the racial wage gap. However, his analysis includes controls for variables which are outcomes of school quality, such as test scores and post-secondary schooling. 
of the test. To the extent AFQT scores measure fixed individual traits that are not altered by human capital investments, racial gaps in these scores should be constant across age groups. However, in both the male and female samples, the estimated racial gaps in scores are larger in the sample of older respondents. ${ }^{45}$ Differences between blacks and whites in both work experience and years of schooling grow with the age of the respondents. Thus, our results are consistent with the hypothesis that differential investment contributes to the black-white gap in scores.

Appendix Table III provides indirect evidence that human capital investments affect AFQT scores. We also provide more direct evidence on the link between schooling and AFQT scores. We ran instrumental variables regressions of standard AFQT scores on dummies for year of birth, dummies for race, and grades of school completed by May of 1980 (the test was administered during the summer of 1980). Again, we use only respondents born after 1961 and run separate regressions for males and females. Following a strategy used by Angrist and Krueger (1991), we use quarter of birth as an instrument for grades completed. ${ }^{46}$

${ }^{45}$ In a sample that includes both cohorts, the standard deviation of standard AFQT scores is 38.01 for men and 35.27 for women. The estimated changes in racial gaps range from -3.5 to -7.03. Using a $10 \%$ level of confidence, all four changes are statistically significant.

${ }^{46}$ In our sample of teenagers, the effect of birth quarter on schooling arises primarily from restrictions on the age when students may enter school. Most localities have rules or guidelines concerning the age a child must be to enter school, and children born in the last quarter of the year often start school a year later than students born earlier in the same calendar year. In our data, the average of grades completed at the time of the 
The results cast more doubt on the claims made by Herrnstein and Murray. For both sexes, the estimated coefficients on grades completed are large and statistically significant. The coefficient estimates imply that an additional year of schooling raises AFQT scores for men and women by .22 and .25 standard deviations respectively. ${ }^{47}$ Thus, the black-white gap in mean scores is roughly equivalent to the skill building effect of just over four years of secondary schooling. ${ }^{48}$

III. Conclusion

Many attempts to measure the wage effects of current labor market discrimination against minorities include controls for worker productivity that (1) could themselves be affected by discrimination and (2) are very imprecise measures of worker skill. The resulting estimates of residual wage gaps may be biased. Our

AFQT declines slightly over the first three quarters of a given birth year and falls substantially between the third and fourth quarters.

${ }^{47}$ By contrast, Herrnstein and Murray claim that an additional year of schooling raises scores by only .07 standard deviations. See Herrnstein and Murray (1994), p.591.

${ }^{48}$ Bound, Jaeger, and Baker (1993) demonstrate that even in large samples, IV estimates may be seriously biased if the instruments are weakly correlated with the potentially endogenous variable. Our partial $R$ squareds for the quarter of birth dummies in the first stage regressions are .074 for men and .046 for women. our F-statistics on the significance of the quarter of birth dummies in the first-stage regressions are 46.6 and 29.3 respectively. According to the criteria set forth by Bound, Jaeger, and Baker, the implied bias is quite small for both males and females. 
approach is a parsimoniously specified wage equation which controls for skill with the score of a test administered as teenagers prepared to leave high school and embark on work careers or postsecondary education. Independent validation studies indicate that this test score is a racially unbiased measure of the skills and abilities these teenagers were about to bring to the labor market. We find that this one test score explains all of the blackwhite gap for young women and much of the gap for young men, a bigger share than has been found by many other studies. For today's young adults, the black-white wage gap primarily reflects a skill gap, which in turn can be traced, at least in part, to observable differences in the family backgrounds and school environments of black and white children.

While our results do provide some evidence of current labor market discrimination, skill gaps play such a large role that we believe future research on the determinants of the black-white wage gap should focus on the obstacles black children face in acquiring productive skill.

Finally, can our results address the well documented trends in the black-white gap? After decades of narrowing, the unadjusted gap has either widened or has failed to shrink further since $1980 .{ }^{49}$ Considerable disagreement exists about the causes of this

\footnotetext{
${ }^{49}$ See Bishop (1991), Bound and Freeman (1992), Ferguson (1993), Juhn, Murphy and Pierce (1991), Card and Krueger (1992) and Smith (1993), for treatments of this issue.

Juhn, Murphy and Pierce (1991) contend that the slowdown in black progress can be accounted for by a rising price of skill and continuing discrepancies in quality between the schooling of blacks and whites. Ferguson (1993) estimates wage regressions for each
} 
recent pattern but several studies emphasize the interaction between black-white skill gaps and the rising value of skill in the 1980 's. While our results are consistent with the view that blacks suffer relative to whites from increases in the market price of skill, there is no logically necessary connection between our findings, which concern cross-section variation, and empirical models of changes over time.

year in the 1980's using AFQT as a measure of skill and argues that a sharply rising price of skill overcoming the modest gains in black skill as measured by test scores can fully account for trends in the black-white wage gap during the decade. Bishop (1991) and Murnane, Levy and willett (1994) also find a rising return to skill as measured by test scores. The rising return to skill is an explanation consistent with the observed increasing inequality of wages within the white workforce. Bound and Freeman (1992) contend that a host of factors, including lower real minimum wages, less unionization, and demand shifts, rather than school quality or skill gaps account for recent patterns in the black-white wage gap.

our results do not directly address the question of changes in the racial wage gap over time because the limited span of birth years in the data mean that we cannot observe changes in the relationship between test scores and wages for workers in their late twenties. In fact by 1990 we can observe wages at age thirty for only three birth cohorts and these three cohorts had left high school before taking the AFQT. 


\section{References}

Angrist, Joshua and Alan Krueger, "Does Compulsory School Attendance Affect Schooling and Earnings?," Quarterly Journal of Economics, November, 1991.

Arrow, Kenneth, "A Theory of Discrimination" in O. Ashenfelter and A. Rees, Eds. Discrimination in the Labor Market, Princeton University Press, 1973.

Bishop, John, "Achievement, Test Scores and Relative Wages," in Marvin Kosters, ed. Workers and their Wages, American Enterprise Institute, Washington, 1991.

Blau, Francine and Andrea Beller,"Black-White Earnings over the 1970s and 1980s: Gender Differences in Trends," Review of Economics and statistics, May 1992.

Blinder, Alan, "Wage Discrimination: Reduced Form and Structural Estimates," Journal of Human Resources, Fall, 1973.

Boozer, Michael, Alan Krueger and Shari Wolkon, "Race and School Quality since Brown v. Board of Education," Brookings Papers on Economic Activity: Microeconomics, 1992.

Bound, John and Richard Freeman, " What Went Wrong ? The Erosion of Relative Earnings and Employment Among Young Black Men in the 1980's" Quarterly Journal of Economics February, 1992.

Bound, John, David Jaeger and Regina Baker, "The Cure can be Worse than the Disease: A Cautionary Tale Regarding Instrumental Variables," forthcoming Journal of the American Statistical Association, June, 1995.

Brown, Charles, "Black-White Earnings Ratios since the Civil Rights Act of 1964: The Importance of Labor Market Dropouts," Quarterly Journal of Economics, February, 1984.

Butler, Richard and James Heckman, "The Government's Impact on the Labor Market Status of Black Americans: A Critical Review," in Leonard J. Hausman et al., eds. Equal Rights and Industrial Relations, Industrial Relations Research Association, 1977.

Cain, Glen, "Labor Market Discrimination" in O. Ashenfelter and R. Layard, eds. Handbook of Labor Economics, Volume 1, NorthHolland, 1986.

Card, David and Alan Krueger, "School Quality and Black-White Relative Earnings: A Direct Assessment," Quarterly Journal of Economics, February, 1992. 
Corcoran, Mary and Greg J. Duncan, "Work History, Labor Force Attachment, and Earnings Differences between the Races and Sexes," Journal of Human Resources, XIV, 1, winter, 1979.

Cutright, Phillips, Achievement, Mobility and the Draft: Their Impact on the Earnings of Men, Social Security Administration, Staff Paper No. 14, 1973.

Donohue, III, John $\mathrm{H}$. and James Heckman, "Continuous versus Episodic Change: the Impact of civil Rights Policy on the Economic Status of Blacks," Journal of Economic Literature, December 1991.

Ferguson, Ronald, "New Evidence on the Growing Value of Skill and Consequences for Racial Disparity and Returns to Schooling," J.F. Kennedy School of Government, Harvard University, September 1993.

Freeman, Richard, "Black Economic Progress after 1964: Who Has Gained and Why?," in studies in Labor Markets, Sherwin Rosen, ed., University of Chicago Press, 1981.

Grogger, Jeff, "Does School Quality Explain the Recent Black/White Wage Trend ?," University of California, Santa Barbara, August 1993.

Herrnstein, Richard and Charles Murray, The Bell Curve, Free Press, 1994

Juhn, Chinhui, Kevin M. Murphy, and Brooks Pierce, "Accounting for the slowdown in Black-White wage Convergence," in Marvin Kosters, ed. Workers and Their Wages, American Enterprise Institute, Washington, 1991.

Lundberg, Shelly and Richard Startz, "Private Discrimination and Social Intervention in Competitive Labor Markets," American Economic Review, June, 1983.

Maxwell, Nan, "The Effect on Black-White Wage Differences of Differences in the Quantity and Quality of Education," Industrial and Labor Relations Review, January, 1994.

Murnane, Richard, Frank Levy and John B. willett, "The Growing Importance of Cognitive Skills in Wage Determination," Review of Economics and Statistics, forthcoming, 1994.

National Center for Educational Statistics, High School and Beyond Survey, 1980 .

Oaxaca, Ronald and Michael R. Ransom, "On Discrimination and the Decomposition of Wage Differentials," Journal of Econometrics, 61, 1, March, 1994. 
O'Neill, June, "The Role of Human Capital in Earnings Differences between Black and White Men," Journal of Economic Perspectives, Fall, 1990.

Reimers, Cordelia, "Labor Market Discrimination against Hispanic and Black Men," Review of Economics and Statistics, LXV, 4, November, 1983.

Smith, James, "Affirmative Action and the Racial Wage Gap," American Economic Review, May, 1993, pp. 79-84.

Smith, James and Finis Welch, closing the Gap: Forty Years of Economic Progress for Blacks, Rand Corporation Report Number 3330, Santa Monica, CA, 1986.

Wigdor, Alexandra and Bert F. Green, Jr., editors, Performance Assessment in the Workplace, Volume 1, National Academy Press, Washington, D.C., 1991. 
Table I

Log Wage Regressions by Sex

\begin{tabular}{|c|c|c|c|c|c|c|}
\hline & \multicolumn{3}{|c|}{ Men } & \multicolumn{3}{|c|}{ Women } \\
\hline & $(1)$ & (2) & (3) & (4) & (5) & $(6)$ \\
\hline $\mathrm{Black}$ & $\begin{array}{l}-.244 \\
(.026) \\
\end{array}$ & $\begin{array}{l}-.072 \\
(.027) \\
\end{array}$ & $\begin{array}{l}-.196 \\
(.025) \\
\end{array}$ & $\begin{array}{r}-.185 \\
(.029) \\
\end{array}$ & $\begin{array}{l}.035 \\
(.031) \\
\end{array}$ & $\begin{array}{r}-.155 \\
(.027) \\
\end{array}$ \\
\hline Hispanic & $\begin{array}{l}-.113 \\
(.030)\end{array}$ & $\begin{array}{l}.005 \\
(.030) \\
\end{array}$ & $\begin{array}{l}-.045 \\
(.029) \\
\end{array}$ & $\begin{array}{c}-.028 \\
(.033) \\
\end{array}$ & $\begin{array}{l}.145 \\
(.032) \\
\end{array}$ & $\begin{array}{l}.057 \\
(.031) \\
\end{array}$ \\
\hline Age & $\begin{array}{l}.048 \\
(.014) \\
\end{array}$ & $\begin{array}{l}.040 \\
(.013) \\
\end{array}$ & $\begin{array}{l}.046 \\
(.013) \\
\end{array}$ & $\begin{array}{l}.010 \\
(.015) \\
\end{array}$ & $\begin{array}{l}.023 \\
(.015) \\
\end{array}$ & $\begin{array}{l}.009 \\
(.014) \\
\end{array}$ \\
\hline $\mathrm{AFQT}$ & -- & $\begin{array}{c}.172 \\
(.012) \\
\end{array}$ & -- & -- & $\begin{array}{l}.228 \\
(.015) \\
\end{array}$ & -- \\
\hline$A F Q T^{2}$ & -- & $\begin{array}{l}-.013 \\
(.011) \\
\end{array}$ & -- & -- & $\begin{array}{l}.013 \\
(.013) \\
\end{array}$ & -- \\
\hline $\begin{array}{l}\text { High Grade } \\
\text { by } 1991\end{array}$ & -- & & $\begin{array}{l}.061 \\
(.005) \\
\end{array}$ & -- & -- & $\begin{array}{l}.088 \\
(.005) \\
\end{array}$ \\
\hline $\mathrm{R}$-squared & .059 & .168 & .155 & .029 & .165 & .191 \\
\hline $\mathrm{N}$ & 1593 & 1593 & 1593 & 1446 & 1446 & 1446 \\
\hline
\end{tabular}

Notes: The dependent variable is the log of hourly wages. The wage observations come from 1990 and 1991. All wages are measured in 1991 dollars. If a person works in both years, the wage is measured as the average of the two wage observations. Wage observations below $\$ 1.00$ per hour or above $\$ 75.00$ are eliminated from the data.

The sample consists of the NLSY cross-section sample plus the supplemental samples of blacks and hispanics. We eliminate all respondents born before 1962. Further, we eliminate respondents who did not take the ASVAB test and respondents for whom the NLSY records document a problem with their test. There are 66 men with valid wage observations who are eliminated solely because of missing or invalid test scores. The corresponding figure for women is 38 .

standard errors in parentheses. 
Table II

Testing for Race Differences in the Return to AFQT: Men

\begin{tabular}{|c|c|c|c|c|}
\hline & All Races & White & Black & Hispanic \\
\hline & (1) & $(2)$ & (3) & (4) \\
\hline Black & $\begin{array}{c}-.107 \\
(.033) \\
\end{array}$ & -- & -- & -- \\
\hline Hispanic & $\begin{array}{l}.003 \\
(.029) \\
\end{array}$ & -- & -- & -- \\
\hline Age & $\begin{array}{c}.038 \\
(.013) \\
\end{array}$ & $\begin{array}{l}.052 \\
(.017) \\
\end{array}$ & $\begin{array}{c}.047 \\
(.025) \\
\end{array}$ & $\begin{array}{l}-.014 \\
(.035)\end{array}$ \\
\hline AFQT & $\begin{array}{l}.172 \\
(.015) \\
\end{array}$ & $\begin{array}{c}.183 \\
(.017) \\
\end{array}$ & $\begin{array}{l}.208 \\
(.031) \\
\end{array}$ & $\begin{array}{l}.124 \\
(.031) \\
\end{array}$ \\
\hline $\mathrm{AFQT}^{2}$ & $\begin{array}{c}-.023 \\
(.013)\end{array}$ & $\begin{array}{c}-.018 \\
(.015)\end{array}$ & $\begin{array}{l}.031 \\
(.025) \\
\end{array}$ & $\begin{array}{c}-.066 \\
(.031) \\
\end{array}$ \\
\hline Black *AFQT & $\begin{array}{c}.037 \\
(.031) \\
\end{array}$ & -- & -- & -- \\
\hline Black *AFQT ${ }^{2}$ & $\begin{array}{l}.055 \\
(.028) \\
\end{array}$ & -- & -- & -- \\
\hline R-Squared & .170 & .155 & .129 & .074 \\
\hline $\mathrm{N}$ & 1593 & 825 & 466 . & 302 \\
\hline
\end{tabular}

Notes: The "all races" sample includes all men from the sample described in Table 1.

All respondents were born after 1961 .

Standard errors in parentheses. 
Table III

Testing for Race Differences in the Return to AFQT: Women

\begin{tabular}{|c|c|c|c|c|}
\hline & All Races & White & Black & Hispanic \\
\hline & (1) & (2) & (3) & (4) \\
\hline Black & $\begin{array}{l}.079 \\
(.037) \\
\end{array}$ & -- & -- & -- \\
\hline Hispanic & $\begin{array}{c}.137 \\
(.034) \\
\end{array}$ & -- & -- & -- \\
\hline Age & $\begin{array}{c}.023 \\
(.015) \\
\end{array}$ & $\begin{array}{c}.017 \\
(.022) \\
\end{array}$ & $\begin{array}{c}.015 \\
(.024) \\
\end{array}$ & $\begin{array}{l}.055 \\
(.030)\end{array}$ \\
\hline $\mathrm{AFQT}$ & $\begin{array}{l}.212 \\
(.019)\end{array}$ & $\begin{array}{l}.189 \\
(.030)\end{array}$ & $\begin{array}{l}.223 \\
(.029)\end{array}$ & $\begin{array}{l}.202 \\
(.030)\end{array}$ \\
\hline $\mathrm{AFQT}{ }^{2}$ & $\begin{array}{c}.031 \\
(.016)\end{array}$ & $\begin{array}{l}.059 \\
(.025)\end{array}$ & $\begin{array}{l}-.039 \\
(.030)\end{array}$ & $\begin{array}{l}-.025 \\
(.029)\end{array}$ \\
\hline Black *AFQT & $\begin{array}{l}-.011 \\
(.038)\end{array}$ & -- & -- & -- \\
\hline Black $\star \mathrm{AFQT}^{2}$ & $\begin{array}{c}-.071 \\
(.037)\end{array}$ & -- & -- & -- \\
\hline R-squared & .168 & .137 & .166 & .154 \\
\hline $\mathbf{N}$ & 1446 & 726 & 428 & 292 \\
\hline
\end{tabular}

Notes: The "all races" sample includes all women from the sample described in Table $I$.

All respondents were born after 1961 .

standard errors in parentheses. 
Table IV

Median Log Wage Regressions: Men

\begin{tabular}{|c|c|c|}
\hline & (1) & (2) \\
\hline Black & $\begin{array}{c}-.352 \\
(.029)\end{array}$ & $\begin{array}{c}-.134 \\
(.035)\end{array}$ \\
\hline Hispanic & $\begin{array}{l}-.180 \\
(.034)\end{array}$ & $\begin{array}{l}-.007 \\
(.038)\end{array}$ \\
\hline Age & $\begin{array}{l}.067 \\
(.015)\end{array}$ & $\begin{array}{l}.055 \\
(.017)\end{array}$ \\
\hline$A F Q T$ & -- & $\begin{array}{l}.206 \\
(.015)\end{array}$ \\
\hline $\mathrm{AFQT}{ }^{2}$ & -- & $\begin{array}{l}-.010 \\
(.014)\end{array}$ \\
\hline $\mathbf{N}$ & 1674 & 1674 \\
\hline
\end{tabular}

Notes: The dependent variable is log hourly wages.

The sample is the sample described in Table I plus the sample of non-participants. Non-participants include workers who report not working between their 1989 and 1991 interviews. Non-participants also include workers who did not work between their 1989 and 1990 interviews and were not interviewed in 1991.

Some respondents are excluded from the previous regression analyses solely because their wage observations are invalid. These respondents are also excluded from this analysis.

All respondents were born after 1961.

standard errors in parentheses. 
Table V

Quantile Regressions for the Upper Tail

of the Conditional Log Wage Distribution: Men

\begin{tabular}{|c|c|c|c|c|}
\hline & \multicolumn{2}{|c|}{ 75th Percentile } & \multicolumn{2}{|c|}{ 90th Percentile } \\
\hline & $(1)$ & (2) & $(3)$ & $(4)$ \\
\hline Black & $\begin{array}{l}-.324 \\
(.037)\end{array}$ & $\begin{array}{l}-.113 \\
(.039)\end{array}$ & $\begin{array}{l}-.196 \\
(.051)\end{array}$ & $\begin{array}{l}-.042 \\
(.051)\end{array}$ \\
\hline Hispanic & $\begin{array}{l}-.123 \\
(.043)\end{array}$ & $\begin{array}{l}.045 \\
(.038)\end{array}$ & $\begin{array}{l}-.018 \\
(.060)\end{array}$ & $\begin{array}{l}.163 \\
(.054)\end{array}$ \\
\hline Age & $\begin{array}{l}.046 \\
(.020)\end{array}$ & $\begin{array}{l}.048 \\
(.019)\end{array}$ & $\begin{array}{l}.056 \\
(.028)\end{array}$ & $\begin{array}{l}.061 \\
(.025)\end{array}$ \\
\hline AFQT & -- & $\begin{array}{l}.202 \\
(.017)\end{array}$ & -- & $\begin{array}{l}.203 \\
(.022)\end{array}$ \\
\hline$A F Q T^{2}$ & -- & $\begin{array}{l}-.007 \\
(.016)\end{array}$ & -- & $\begin{array}{l}-.012 \\
(.021)\end{array}$ \\
\hline $\mathrm{N}$ & 1674 & 1674 & 1674 & 1674 \\
\hline
\end{tabular}

Notes: The dependent variable is log hourly wages.

The sample is the sample described in Table I plus the sample of non-participants. Non-participants include workers who report not working between their 1989 and 1991 interviews. Non-participants also include workers who did not work between their 1989 and 1990 interviews and were not interviewed in 1991 .

Some respondents are excluded from the previous regression analyses solely because their wage observations are invalid. These respondents are also excluded from this analysis.

All respondents were born after 1961 .

Standard errors in parentheses. 
Table VI

Quantile Regressions for the Upper Tail

of the Conditional Log Wage Distribution: Women

\begin{tabular}{|c|c|c|c|c|}
\hline & \multicolumn{2}{|c|}{ 75th Percentile } & \multicolumn{2}{|c|}{ 9oth Percentile } \\
\hline & (1) & $(2)$ & (3) & $(4)$ \\
\hline Black & $\begin{array}{l}-.319 \\
(.040)\end{array}$ & $\begin{array}{l}-.000 \\
(.038)\end{array}$ & $\begin{array}{l}-.283 \\
(.047)\end{array}$ & $\begin{array}{l}-.065 \\
(.044)\end{array}$ \\
\hline Hispanic & $\begin{array}{l}-.120 \\
(.045)\end{array}$ & $\begin{array}{l}.133 \\
(.039)\end{array}$ & $\begin{array}{l}-.078 \\
(.053)\end{array}$ & $\begin{array}{c}.118 \\
(.045)\end{array}$ \\
\hline Age & $\begin{array}{l}.018 \\
(.022)\end{array}$ & $\begin{array}{l}.022 \\
(.018)\end{array}$ & $\begin{array}{l}.030 \\
(.027)\end{array}$ & $\begin{array}{l}.022 \\
(.021)\end{array}$ \\
\hline $\mathrm{AFQT}$ & -- & $\begin{array}{l}.298 \\
(.018)\end{array}$ & -- & $\begin{array}{c}.273 \\
(.021)\end{array}$ \\
\hline $\mathrm{AFQT}^{2}$ & -- & $\begin{array}{l}-.038 \\
(.016)\end{array}$ & -- & $\begin{array}{c}-.034 \\
(.020)\end{array}$ \\
\hline $\mathbf{N}$ & 1679 & 1679 & 1679 & 1679 \\
\hline
\end{tabular}

Notes: The dependent variable is the log of hourly wage. See notes for Table $v$.

All respondents were born after 1961.

Standard errors in parentheses. 
Determinants of AFQT: Men

\begin{tabular}{|c|c|c|c|c|}
\hline & \multicolumn{3}{|c|}{ Full Sample } & \multirow{2}{*}{$\begin{array}{c}\begin{array}{c}\text { Valid Response } \\
\text { to School } \\
\text { Survey }\end{array} \\
\text { (4) }\end{array}$} \\
\hline & $(1)$ & $(2)$ & (3) & \\
\hline Black & $\begin{array}{r}-1.03 \\
(.05) \\
\end{array}$ & $\begin{array}{l}-.70 \\
(.05))\end{array}$ & $\begin{array}{l}-.57 \\
(.05) \\
\end{array}$ & $\begin{array}{r}-. .42 \\
(.07) \\
\end{array}$ \\
\hline Hispanic & $\begin{array}{l}-.70 \\
(.06) \\
\end{array}$ & $\begin{array}{r}-.31 \\
(.05) \\
\end{array}$ & $\begin{array}{l}-.22 \\
(.05) \\
\end{array}$ & $\begin{array}{l}-.02 \\
(.08)\end{array}$ \\
\hline $\begin{array}{l}\text { Mother High School } \\
\text { Graduate }\end{array}$ & -- & $\begin{array}{l}.36 \\
(.04) \\
\end{array}$ & $\begin{array}{l}.26 \\
(.04) \\
\end{array}$ & $\begin{array}{c}.18 \\
(.06) \\
\end{array}$ \\
\hline Mother College Graduate & -- & $\begin{array}{l}.21 \\
(.08) \\
\end{array}$ & $\begin{array}{l}.16 \\
(.08) \\
\end{array}$ & $\begin{array}{c}.09 \\
(.11) \\
\end{array}$ \\
\hline $\begin{array}{l}\text { Father High School } \\
\text { Graduate }\end{array}$ & -- & $(.32)$ & $\begin{array}{l}.25 \\
(.05) \\
\end{array}$ & $\begin{array}{r}.22 \\
(.06) \\
\end{array}$ \\
\hline Father College Graduate & -- & $(.32)$ & $\begin{array}{l}.30 \\
(.07) \\
\end{array}$ & $(.091)$ \\
\hline Mother Professional & -- & $\begin{array}{l}.20 \\
(.07) \\
\end{array}$ & $\begin{array}{l}.17 \\
(.07) \\
\end{array}$ & $\begin{array}{c}.08 \\
(.10) \\
\end{array}$ \\
\hline Father Professional & -- & $\begin{array}{l}.26 \\
(.06) \\
\end{array}$ & $\begin{array}{l}.23 \\
(.06) \\
\end{array}$ & $\begin{array}{c}.21 \\
(.08) \\
\end{array}$ \\
\hline Number of Siblings & & & $\begin{array}{l}-.05 \\
(.01) \\
\end{array}$ & $\begin{array}{l}-.05 \\
(.01) \\
\end{array}$ \\
\hline No Reading Materials & & & $\begin{array}{l}-.19 \\
(.06)\end{array}$ & $\begin{array}{l}-.31 \\
(.09)\end{array}$ \\
\hline $\begin{array}{l}\text { Numerous Reading } \\
\text { Materialg }\end{array}$ & & & $\begin{array}{l}.25 \\
(.04) \\
\end{array}$ & $\begin{array}{l}.27 \\
(.06) \\
\end{array}$ \\
\hline student-Teacher Ratio & & & & $\begin{array}{l}-.017 \\
(.006) \\
\end{array}$ \\
\hline $\begin{array}{l}\text { Disadvantaged student } \\
\text { Ratio }\end{array}$ & & & & $\begin{array}{l}-.002 \\
(.001)\end{array}$ \\
\hline Drop out Rate. & & & & $\begin{array}{l}-.004 \\
(.001)\end{array}$ \\
\hline Teacher Turnover Rate & & & & $\begin{array}{l}-.005 \\
(.003) \\
\end{array}$ \\
\hline R-Squared & .219 & .382 & .415 & .392 \\
\hline $\mathbf{N}$ & 1873 & 1873 & 1873 & 954 \\
\hline
\end{tabular}

Notes: The dependent variable is the age-adjusted AFoT score. In all specifications, the sample excludes respondents with invalid AFQT scorea. In specification (4). the sample also excludes respondents with invalid responses to the school survey items employed in column (4). Specifications (3) and (4) also include dummies for whether or not the respondent has knowledge of the educational background of their mother or father. (4) also includes a private school dummy. The estimated coefficient is positive but not statistically significant. All background information comes from the 1979 wave of the NLSY. The dumny variables for reading materials are constructed from information about magazines, newspapers, and library cards in the home. "Numerous" means all of the above. "No" means none of the above.

All respondents were born after 1961.

standard errors in parentheses. 
Table VIII

Determinantg of AFQT: Women

\begin{tabular}{|c|c|c|c|c|}
\hline & \multicolumn{3}{|c|}{ Full sample } & \multirow{2}{*}{$\begin{array}{l}\text { Valid Response } \\
\text { to Scbool Surveg } \\
(4)\end{array}$} \\
\hline & (1) & $(2)$ & (3) & \\
\hline Black & $\begin{array}{l}-.99 \\
(.04)\end{array}$ & $\begin{array}{l}-.72 \\
(.04) \\
\end{array}$ & $\begin{array}{l}-.62 \\
(.04) \\
\end{array}$ & $\begin{array}{l}-.58 \\
(.06) \\
\end{array}$ \\
\hline Hispanic & $\begin{array}{l}-.77 \\
(.05)\end{array}$ & $\begin{array}{l}-.45 \\
(.05)\end{array}$ & $\begin{array}{l}-.37 \\
(.05)\end{array}$ & $\begin{array}{l}-.30 \\
(.07)\end{array}$ \\
\hline $\begin{array}{l}\text { Mother High School } \\
\text { Graduate }\end{array}$ & -- & $\begin{array}{l}.29 \\
(.04) \\
\end{array}$ & $\begin{array}{l}.20 \\
(.04) \\
\end{array}$ & $\begin{array}{l}.20 \\
(.06) \\
\end{array}$ \\
\hline Mother College Graduate & -- & $(.08)$ & $(.08)$ & $\begin{array}{l}.24 \\
(.11) \\
\end{array}$ \\
\hline $\begin{array}{l}\text { Father High School } \\
\text { Graduate }\end{array}$ & -- & $\begin{array}{l}.24 \\
(.04) \\
\end{array}$ & $\begin{array}{l}.18 \\
(.04) \\
\end{array}$ & $\begin{array}{l}.12 \\
(.06)\end{array}$ \\
\hline Father College Graduate & -- & $\begin{array}{l}.32 \\
(.07) \\
\end{array}$ & $\begin{array}{l}.29 \\
(.07)\end{array}$ & $(.31)$ \\
\hline Mother Professional & -- & $(.15)$ & $\begin{array}{l}.09 \\
(.07) \\
\end{array}$ & $\begin{array}{l}.16 \\
(.09)\end{array}$ \\
\hline Father Professional & -- & $\begin{array}{l}.15 \\
(.05)\end{array}$ & $(.13)$ & $\begin{array}{l}.07 \\
(.07) \\
\end{array}$ \\
\hline Number of Siblings & & & $\begin{array}{l}-.027 \\
(.007)\end{array}$ & $\begin{array}{l}-.026 \\
(.010)\end{array}$ \\
\hline No Reading Materialo & & & $\begin{array}{l}-.29 \\
(.06) \\
\end{array}$ & $\begin{array}{l}-.21 \\
(.08) \\
\end{array}$ \\
\hline $\begin{array}{l}\text { Numerous Reading } \\
\text { Materials }\end{array}$ & & & $\begin{array}{l}.23 \\
(.04) \\
\end{array}$ & $\begin{array}{l}.23 \\
(.05) \\
\end{array}$ \\
\hline Student-Teacher Ratio & & & & $\begin{array}{l}-.0043 \\
(.0025)\end{array}$ \\
\hline $\begin{array}{l}\text { Disadvantaged Student } \\
\text { Ratio }\end{array}$ & & & & $\begin{array}{l}-.002 \\
(.001)\end{array}$ \\
\hline Drop Out Rate & & & & $\begin{array}{l}-.003 \\
(.001)\end{array}$ \\
\hline Teacher Turnover Rate & & & & $\begin{array}{l}-.003 \\
(.003)\end{array}$ \\
\hline R-Squared & .244 & .390 & .420 & .431 \\
\hline $\mathbf{N}$ & 1791 & 1791 & 1791 & 926 \\
\hline
\end{tabular}

Notes:

See Table 7 . 
Appendix Table I

Descriptive statistics

\begin{tabular}{|c|c|c|c|c|c|c|}
\hline & \multicolumn{3}{|c|}{ Men } & \multicolumn{3}{|c|}{ Women } \\
\hline & Black & Hispanic & White & Black & Hispanic & White \\
\hline $\begin{array}{l}\text { Age adjusted } \\
\text { AFQT score }\end{array}$ & $\begin{array}{l}-.621 \\
(.815) \\
\end{array}$ & $\begin{array}{l}-.284 \\
(.893) \\
\end{array}$ & $\begin{array}{l}.422 \\
(.895) \\
\end{array}$ & $\begin{array}{l}-.524 \\
(.743) \\
\end{array}$ & $\begin{array}{l}-.298 \\
(.825) \\
\end{array}$ & $\begin{array}{l}.465 \\
(.779) \\
\end{array}$ \\
\hline $\begin{array}{l}\text { High grade } \\
\text { completed by } \\
1991\end{array}$ & $\begin{array}{l}12.458 \\
(1.954)\end{array}$ & $\begin{array}{l}12.156 \\
(2.238)\end{array}$ & $\begin{array}{l}13.248 \\
(2.511)\end{array}$ & $\begin{array}{l}12.873 \\
(1.984)\end{array}$ & $\begin{array}{l}12.328 \\
(2.239)\end{array}$ & $\begin{array}{l}13.347 \\
(2.388)\end{array}$ \\
\hline $\begin{array}{l}\text { Mom-High School } \\
\text { Graduate }\end{array}$ & .490 & .336 & .757 & .457 & .280 & .714 \\
\hline $\begin{array}{l}\text { Dad-High School } \\
\text { Graduate }\end{array}$ & .493 & .369 & .717 & .474 & .372 & .717 \\
\hline $\begin{array}{l}\text { Mom-College } \\
\text { Graduate }\end{array}$ & .065 & .041 & .112 & .063 & .032 & .110 \\
\hline $\begin{array}{l}\text { Dad-College } \\
\text { Graduate }\end{array}$ & .062 & .074 & .210 & .071 & .067 & .187 \\
\hline Mom-Professional & .076 & .061 & .106 & .103 & .064 & .104 \\
\hline Dad-Professional & .042 & .090 & .287 & .066 & .106 & .270 \\
\hline
\end{tabular}

These descriptive statistics are for persons who were born between 1962 and 1964 and have valid responses to the relevant questionnaire items. Blacks account for approximately $30 \%$ of the total observations. Hispanics account or $20 \%$ The total sample size is roughly 3400 , but the total number of observations varies across survey items. 
Appendix Table II

Log Wage Regressions with Schooling and AFQT : Men

\begin{tabular}{|c|c|c|c|c|c|c|}
\hline & \multicolumn{3}{|c|}{ Blacks } & \multicolumn{3}{|c|}{ Whites } \\
\hline & (1) & (2) & (3) & (1) & $(2)$ & (3) \\
\hline Constant & $\begin{array}{l}4.566 \\
(.689) \\
\end{array}$ & $\begin{array}{l}4.086 \\
(.752) \\
\end{array}$ & $\begin{array}{l}5.011 \\
(.679) \\
\end{array}$ & $\begin{array}{l}4.926 \\
(.464) \\
\end{array}$ & $\begin{array}{l}4.743 \\
(.504) \\
\end{array}$ & $\begin{array}{l}5.333 \\
(.452) \\
\end{array}$ \\
\hline Age & $\begin{array}{l}.051 \\
(.025) \\
\end{array}$ & $\begin{array}{l}.091 \\
(.027) \\
\end{array}$ & $\begin{array}{l}.059 \\
(.025) \\
\end{array}$ & $\begin{array}{l}.054 \\
(.017) \\
\end{array}$ & $\begin{array}{l}.075 \\
(.018) \\
\end{array}$ & $\begin{array}{l}.053 \\
(.017) \\
\end{array}$ \\
\hline $\mathrm{AFQT}$ & $\begin{array}{l}.122 \\
(.033) \\
\end{array}$ & $\begin{array}{l}.157 \\
(.031) \\
\end{array}$ & $\begin{array}{l}.139 \\
(.031) \\
\end{array}$ & $\begin{array}{l}.125 \\
(.020) \\
\end{array}$ & $\begin{array}{l}.154 \\
(.019) \\
\end{array}$ & $\begin{array}{l}.131 \\
(.019) \\
\end{array}$ \\
\hline$A F Q T^{2}$ & $\begin{array}{l}-.024 \\
(.025) \\
\end{array}$ & $\begin{array}{l}.022 \\
(.025) \\
\end{array}$ & $\begin{array}{r}-.012 \\
(.025) \\
\end{array}$ & $\begin{array}{l}-.030 \\
(.015) \\
\end{array}$ & $\begin{array}{l}-.030 \\
(.015) \\
\end{array}$ & $\begin{array}{l}-.036 \\
(.016)\end{array}$ \\
\hline $\begin{array}{l}\text { High Grade in } \\
1991\end{array}$ & $\begin{array}{l}.059 \\
(.012) \\
\end{array}$ & & & $\begin{array}{l}.035 \\
(.007) \\
\end{array}$ & & \\
\hline $\begin{array}{l}\text { School Years } \\
\text { Since AFQT }\end{array}$ & & $\begin{array}{l}.050 \\
(.012) \\
\end{array}$ & & & $\begin{array}{l}.024 \\
(.008) \\
\end{array}$ & \\
\hline $\begin{array}{l}\text { High School } \\
\text { Graduate }\end{array}$ & & & $\begin{array}{l}.094 \\
(.044) \\
\end{array}$ & & & $\begin{array}{l}.074 \\
(.036) \\
\end{array}$ \\
\hline $\begin{array}{l}\text { College } \\
\text { Graduate }\end{array}$ & & & $\begin{array}{l}.270 \\
(.067) \\
\end{array}$ & & & $\begin{array}{l}.187 \\
(.038) \\
\end{array}$ \\
\hline R-Squared & .175 & .159 & .170 & .178 & .165 & .186 \\
\hline $\mathrm{N}$ & 466 & 466 & 466 & 825 & 825 & 825 \\
\hline
\end{tabular}

Implied Black-White Gap

\begin{tabular}{|c|c|c||}
\hline Specification & $x=$ Black Sample Mean & $x=$ White Sample Mean \\
\hline \hline 1 & -.093 & -.073 \\
& $(.029)$ & $(.038)$ \\
\hline 2 & -.077 & -.057 \\
& $(.030)$ & $(.038)$ \\
\hline 3 & -.080 & -.054 \\
& $(.029)$ & $(.038)$ \\
\hline
\end{tabular}

Notes: The dependent variable is log hourly wages.

All respondents were born after 1961 .

Standard errors in parentheses. 


\section{Appendix Table III}

Racial Gaps in Standard AFQT scores

by sex and Cohort

\begin{tabular}{|c|c|c|c|c|}
\hline & \multicolumn{2}{|c|}{ Males } & \multicolumn{2}{|c|}{ Females } \\
\hline & $\begin{array}{c}\text { Born } \\
1962-64 \\
\end{array}$ & $\begin{array}{c}\text { Born } \\
1957-61\end{array}$ & $\begin{array}{c}\text { Born } \\
1962-64\end{array}$ & $\begin{array}{c}\text { Born } \\
1957-61\end{array}$ \\
\hline Black & $\begin{array}{r}-39.25 \\
(1.76)\end{array}$ & $\begin{array}{r}-46.28 \\
(1.57)\end{array}$ & $\begin{array}{r}-37.52 \\
(1.64)\end{array}$ & $\begin{array}{r}-40.92 \\
(1.38)\end{array}$ \\
\hline Hispanic & $\begin{array}{r}-27.26 \\
(2.10)\end{array}$ & $\begin{array}{r}-31.82 \\
(1.84)\end{array}$ & $\begin{array}{r}-28.85 \\
(1.87)\end{array}$ & $\begin{array}{r}-35.85 \\
(1.63)\end{array}$ \\
\hline R-squared & .23 & .27 & .25 & .28 \\
\hline $\mathrm{N}$ & 1882 & 2579 & 1806 & 2807 \\
\hline
\end{tabular}

The dependent variable is the standard AFQT score. Scores range from 95 to 258. In the cross-section subsample of the NLSY, the mean score is 196.5 and the standard deviation is 36.65. Each regression includes dummies for year of birth. 


\section{FIGURE I \\ MALE PARTICIPATION RATES 1990}

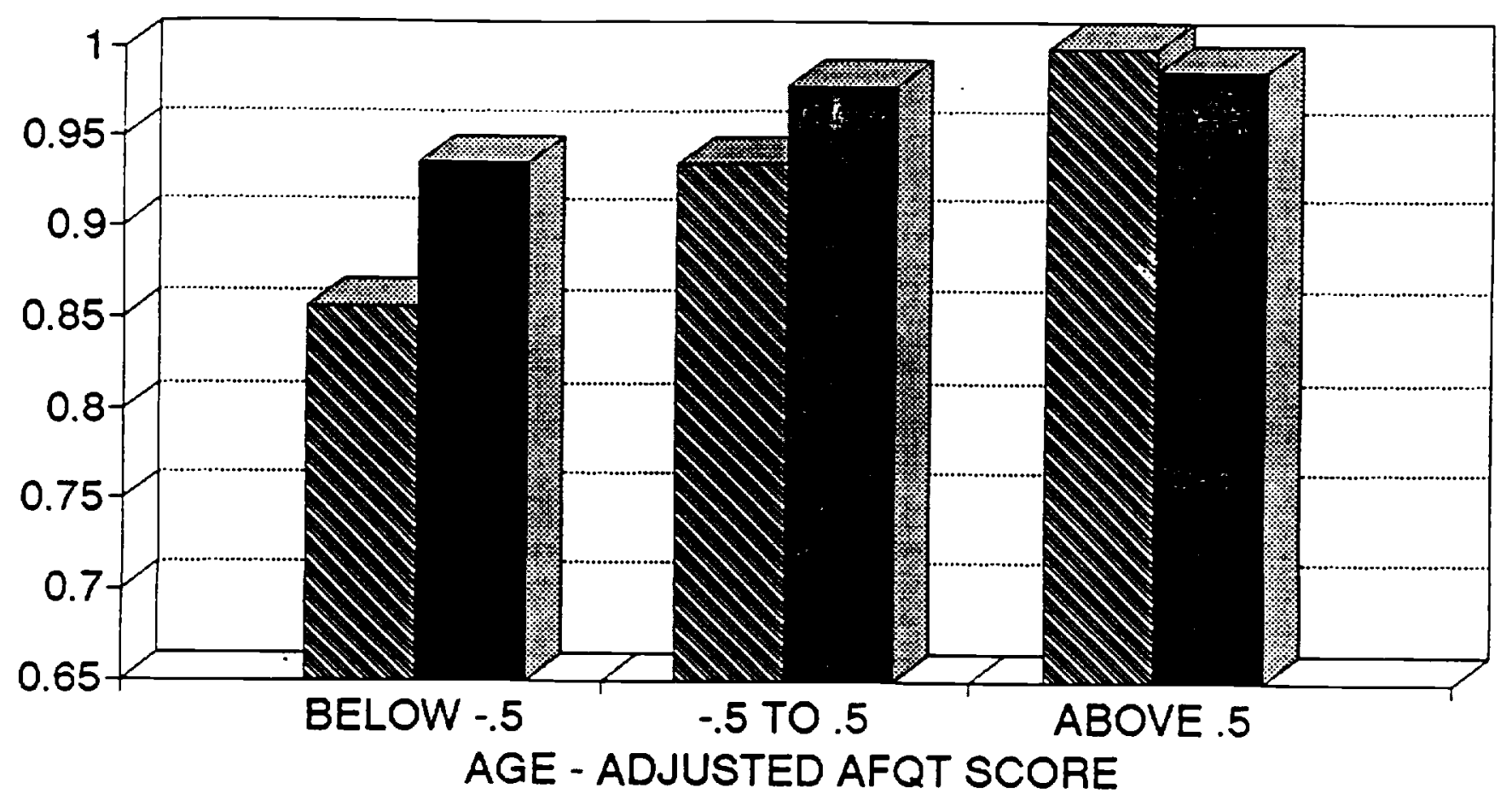

BLACK WHITE




\section{FIGURE II \\ Age Adjusted AFQT Scores - Men}

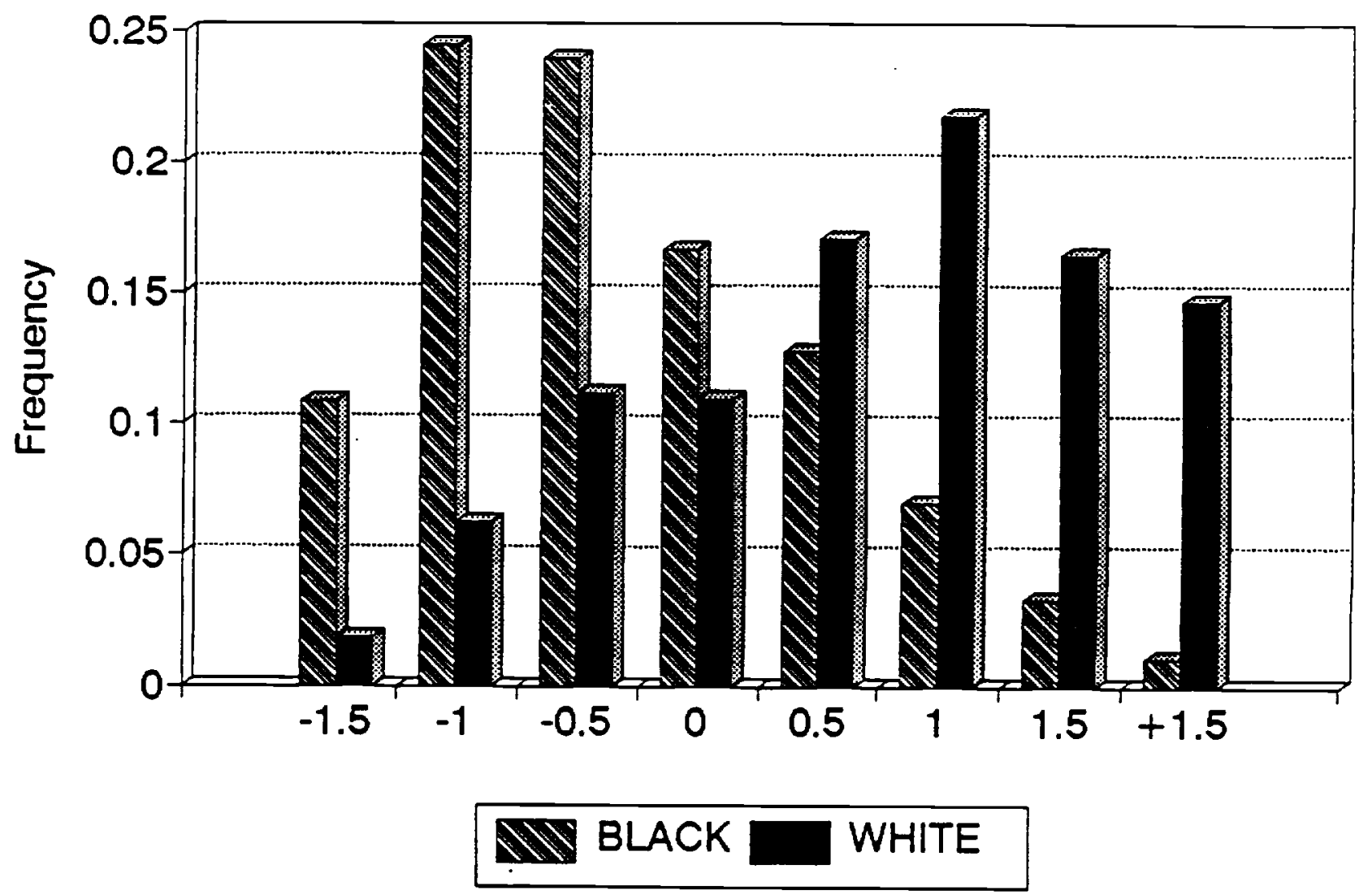




\section{FIGURE III \\ Age Adjusted AFQT Scores - Women}

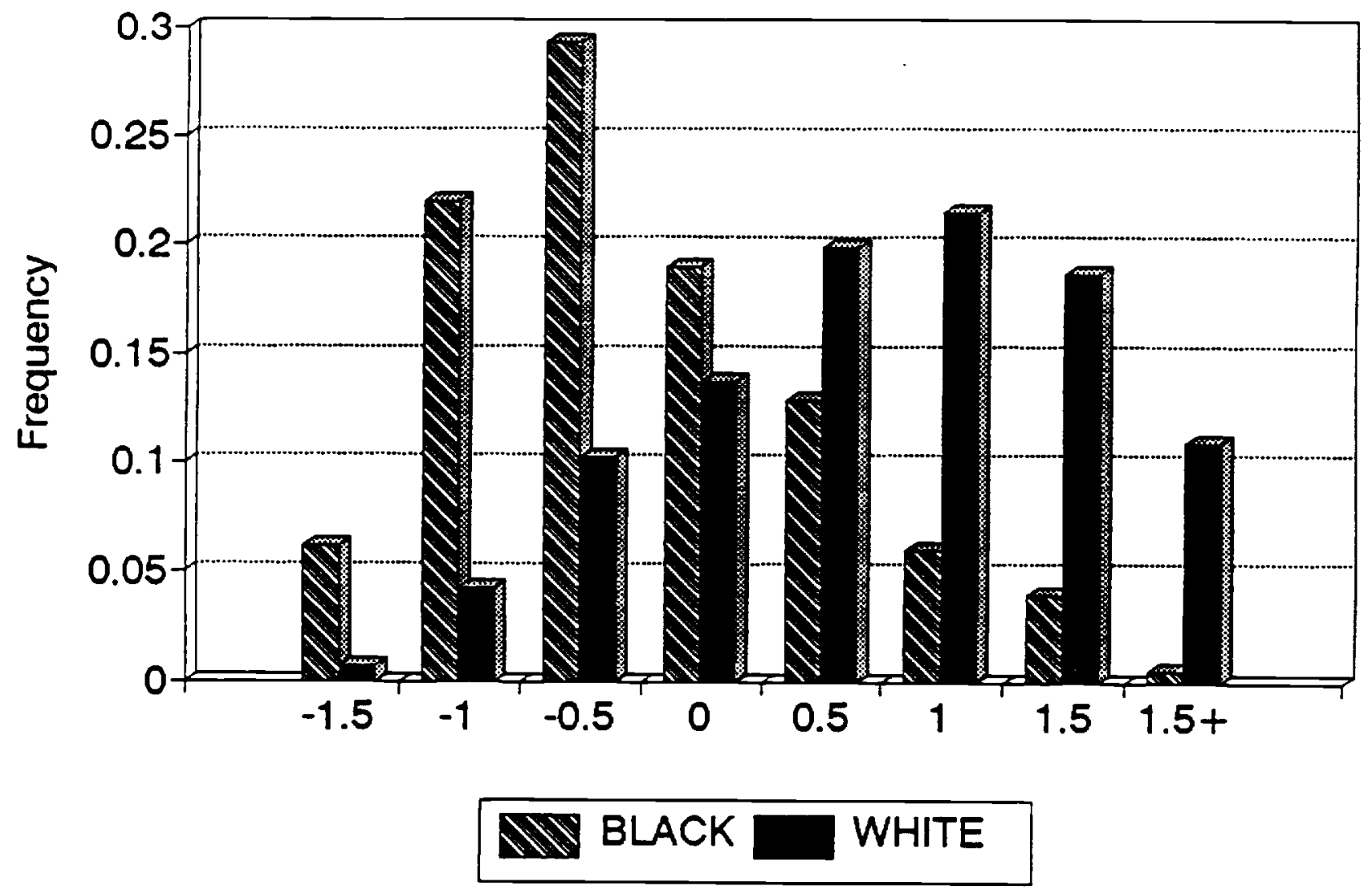

